УДК 331.103 .22

\title{
ОРГАНІЗАЦІЯ РОБОТИ МЕНЕДЖЕРІВ ТА ПРИЙНЯТТЯ РІШЕНЬ
}

() О. М. Барзилович, О. С. Євдоніна, НТУУ «КПІ», Київ, Україна

В литературе по менеджменту описываются виды менеджерских стилей, тренингов, клубов, стилей управления, делегирования, внедрения инноваций, привлечения работников, финансовых вливаний и групповой работы. Но все это можно объединить лишь в несколько видов и эффективно использовать в работе.

Management literature describes numerous management styles, autocratic, coaching, country club, directing, delegating, laissez-faire, participatory, supportive and team-based. All this styles could be unite in couple and working effective.

\section{Постановка проблеми}

На данному етапі в Україні багато іноземних компаній відкривають свої філії та офіси і працюють за новітніми західними методиками, щодо організації робочого процесу.

Багато сучасних українських компаній і досі працюють за старими радянськими методиками, але $€$ й ті, що прагнуть оновлювати свої компанії і запроваджують для своїх робітників спеціальні тренінги, які допомогли б їм продуктивніще виконувати свої обов'язки і краще почувати себе в колективі.

\section{Аналіз попередніх досліджень}

На данний момент в літературі вирізняють багато різновидів управлінських завдань, але проаналізувавши їх можна виділити три:

1) пов'язані 3 довгостроковим плануванням, прогнозуваням, виділення стратегічних завдань;
2) пов'язані з техніко-технологічними питаннями;

3) пов'язані з людським фактором, соціально-психологічним кліматом та кадровими питаннями [3].

У найбільш загальній формі управлінське рішення повинне охоплювати:

а) мета (сукупність цілей) функціонування і розвитку системи;

б) кошти і ресурси, використовувані для досягнення цих цілей;

в) основні шляхи і способи досягнення цілей;

г) терміни досягнення цілей;

д) порядок взаємодії між підрозділами і виконавцями;

е) організацію виконання робіт на всіх етапах реалізації рішення [2].

За методом прийняття управлінські методи можна поділити на три:

1. Інтуїтивні рішення.

2. Основані на судженнях. 
3. Раціональні рішення [4].

Інтуїтивне рішення - це вибір, зроблений лише на основі відчуття того, що воно правильне. Головна різниця між рацінальним рішенням і основаним на судженнях в тому, що перше не залежить від попереднього досвіду. Раціональне рішення залежить від об'єктивного аналітичного процесу.

Часто при прийнятті рішень у керівника можуть виникнути певні проблеми, такі як спроба вирішення одночасно великого об'єму робіт, витрата сил на незначні проблеми, які заважають вирішенню дійсно важливих. Саме через це керівник повинен навчитися визначати першочергові проблеми, які потребують уваги та другорядні, якими можна зайнятися пізніше або за допомогою делегування доручити їх підлеглим. Якщо слідувати цьому принципу легше вкладатися у встановлені терміни, одержувати задоволення від робочого дня та результатів, уникати конфліктів, стресових ситуацій і перевантажень.

Визначити першочерговість справможливо за допомогою кількох методів.

Принцип Парето. Визначає, що серед усієї маси питань, що необхідно вирішити лише невелика частина з них має велику значимість. Відповідно до цієї теорії за весь час, витрачений на вирішення питань лише $20 \%$ витрачаються продуктивно складають 80 \% всього результату, а інші 80 \% приносять лише 20 \% загального результату [1].

Встановлення пріоритетів за допомогою аналізу АБВ. За допомогою букв А,Б і В задачі по своїй важливості розподіляються на три групи. Аналіз АБВ ґрунтується на трьох закономірностях:

- Найважливіші задачі складають приблизно 15 \% усієї кількості справ, якими займається керівник. Внесок цих задач складає біля $65 \%$.

- На важливі задачі припадає близько 20 \% загального числа справ, значимість котрих також складає близько $20 \%$.

- Менш важливі задачі складають біля 65 \% усіх справ, а в свою чергу значимість їх складає усього лише $15 \%$.

Для застосування методу АБВ необхідно: скласти список задач; систематизувати їх по важливості і встановити чергу; оцінити їх за шкалою АБВ; задачі категорії A (15 \%) не підлягають передачі; задачі категорії Б (20 \%) делегуються; задачі категорії В підлягають обов'язковії передачі [1].

Прискорений аналіз за принципом Ейзенхауера [2].

Цей принцип є простим допоміжним засобом у тих випадках, коли необхідно швидко прийняти рішення щодо того, якій задачі віддати перевагу. Пріоритети встановлюються по таких критеріях як терміновість і важливість справи. Вони підрозділяються на 4 групи:

1) Термінов і важливої справи - необхідно виконати самому керівнику.

2) Термінов і менше важливі справи.

3) Менше термінов і важливі задачі. Необв'язково виконувати їх відразу, але виконувати їх треба самому. 
4) Менше термінові і менше важливої справи. Від задач менше термінових і несуттєвих варто утримуватися.

Завдяки принципу Ейзенхауера можна істотно збільшити продуктивність і результативність.

Процес передачі керівником менш важливих задач своїм підлеглим називається делегуванням. Але при цьому начальник зберігає за собою відповідальність за керівництво, що не може бути делегована [4].

Передача задач або діяльності може здійснюватися на тривалий термін або обмежуватися разовими дорученнями.

Виділяють три найголовніщі стилі прийняття рішень.

Директивний стиль полягає в тому, що керівник сам вирішує як розв'язати проблему, хто з підлеглих має виконати завдання, як його виконати та в який термін. Керівник, що обирає такий стиль керування бере всю відповідальність на себе і приймає усі рішення самостійно, незважаючи на їх важливість і першочерговість.

Дискусійний стиль полягає в тому, що всі питання вирішуються способом обговорення на зборах керівників підрозділів та найкращіх працівників. Таким чином керівник дає можливість працівникам брати участь в управлінні та відчуваюти свою причетність і важливість [5].

Делегувальний стиль несе в собі вирішення всіх питань таким чином, коли керівник частину своїх повноважень віддає своїм підлеглим і встановлює строки виконання, а от спосіб, яким буде досягнуто цілі обирає сам підлеглий. Стиль певним чином поєднує два попередні, беручи від них найкраще.

\section{Мета роботи}

Для майбутнього розвитку держави дуже важливим є прийняття рішень в узгодженому порядку і таким чином, щоб результати були найпродуктивнішими. Саме тому нижче будуть розглянуті методики, які застосовують в Японії та Німеччині, а також прийняття рішень на Київській офсетній фабриці (КОФ).

\section{Результати дослідження}

Розглядаючи японську і німецькі системи керівництва можна порівняти найкращі принципи управління розвинутих країн сходу і заходу і почерпнути з них найнеобхідніше для нас.

Значний інтерес становить досвід Японії в галузі керівництва організаціями. Основними положеннями японської системи управління $€$ такі:

- працівники отримують задоволення залежно від щільності вертикального зв'язку в організації;

- основним завданням менеджера $€$ забезпечення підтримки працівників в одержанні необхідної інформації та в процедурах реалізації цілей діяльності групи;

- при груповому прийнятті рішень усі члени колективу повинні вносити вклад у досягнення мети в повну міру своїх можливостей;

- усередині колективу, який сформувався на засадах прихильності до однієї загальної справи, почуття єдності забез- 


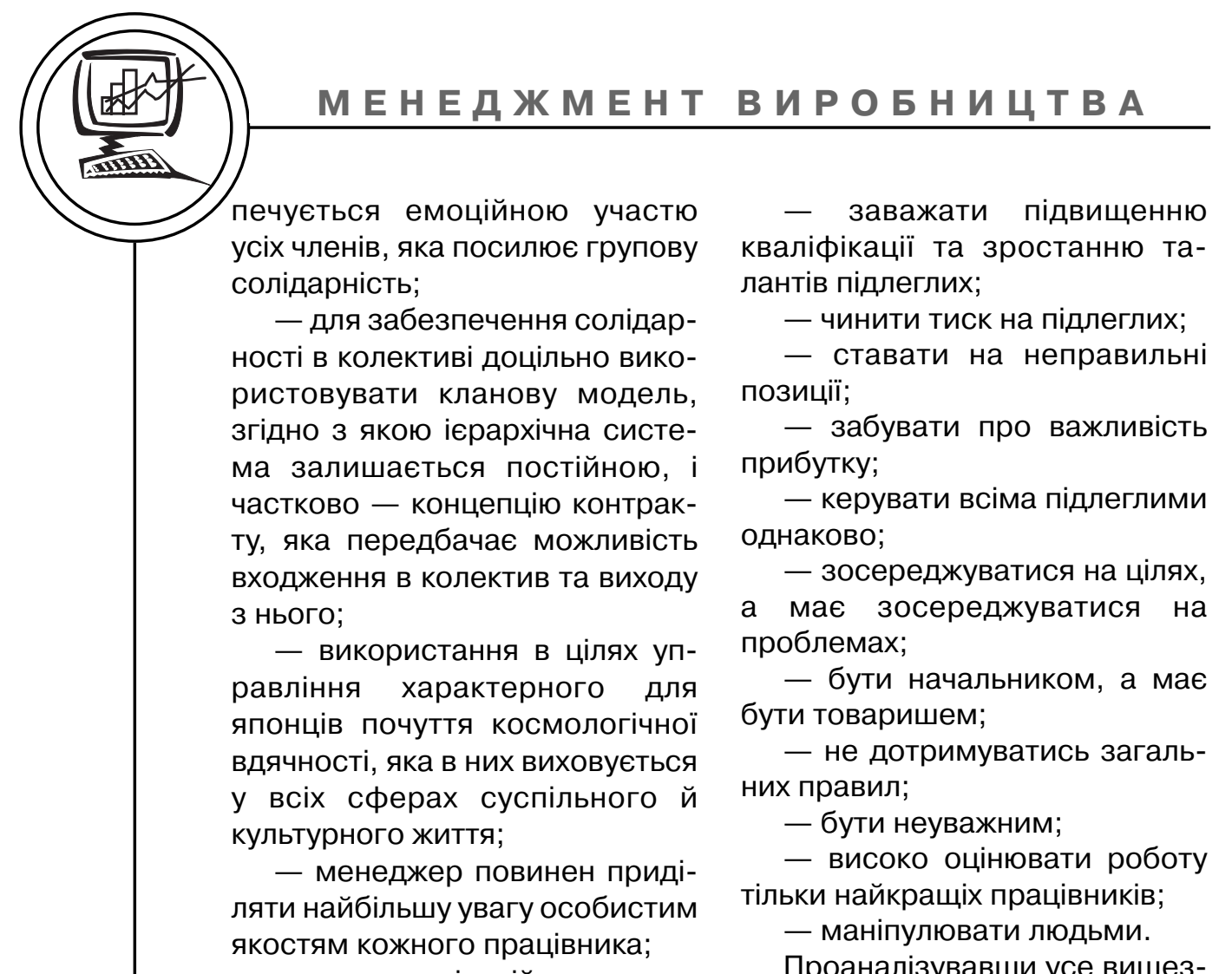

- у процесі здійснення керівництва менеджеру слід спиратись на розуміння того, що в японців сильно розвинуте почуття взаємозалежності;

- керівник повинен найбільш тривалий час протягом робочого дня перебувати на виробництві;

- службовці, які мають знання, $€$ «ноу-хау» компанії;

- працівники, які застосовують нововведення, підвищують продуктивність праці і якість, повинні постійно заохочуватися, відчувати, що до їхніх вимог та міркувань керівництво прислуховується [6].

Німецька система «смертних гріхів» Вольфганга Хойєра побудована на принципах відкидання неправомірних та неефективних дій. Згідно з цією системою менеджер не повинен:

- відмовлятися від особистої відповідальності;

Проаналізувавши усе вищезгадане можна зробити висновок, що менеджер повинен так організувати свою працю та вплинути на людей таким чином, щоб останні виконували роботу, доручену організації відповідно до її місії та цілей [7].

Якщо ж казати про КОФ, то там всі рішення приймаються на засіданні технічної ради, до складу якої входять керівники підрозділів. Виконання менш важливих завдань зазвичай доручаються молодшим працівникам і результати проведених дій обговорюються на щотижневих зборах керівництва, на яких також оголошують завдання і дії на наступний тиждень. Таким чином стає зрозуміло, що на КОФ застосовується поєднання дискусійного стилю і стилю делегування, які керівництво успішно поєднує. Але треба враховувати ще й такий момент, що КОФ знаходиться при Міні- 
стерстві Фінансів України і найважливіші рішення приймаються саме там.

\section{Висновки}

В результаті дослідження можна зробити висновок, що методи прийняття рішень та організація роботи менеджерів за- лежить від керівника, який і визначає, яким саме методом приймати рішення, чи брати всю відповідальність за прийняття рішень на себе, чи дозволяти працівникам брати в цьому участь, проявляти ініціативу та проявляти свою спроможність креативність і відповідальність.

1. Шегда А. В. Менеджмент: Навчальний посібник. - К.: Знання. 2002. - С. 584. 2. Кричевський Р. Л. Если вы руководитель. - М.: Дело, 1996. З. Ладанов И. Д. Практический менеджмент. - М.: Элник, 1995. 4. Зайверт Л. Интерэксперт, 1995. 5. Мескон М. Х., Альберт М., Хэдоуи Ф. Основы менеджмента. - М.: Дело, 1992. 6. Paol B. Thornton. com/!bigthree.html. 7. Андрушків Б. М., Кузьмін О. Е. Основи менеджменту. - Львів: Світ, 1995. - С. 423. 8. Сладкевич В. П., Чернявський А. Д. Современний менеджмент. - К., 2002. - С. 150. 